\title{
Composting of biodegradable municipal waste in Ireland
}

\author{
N. M. Power \& J. D. Murphy \\ Department of Civil, Structural and Environmental Engineering, \\ Cork Institute of Technology, Cork, Ireland
}

\begin{abstract}
The implementation of the Landfill Directive (96/31/EC) will lead to a massive reduction in quantities of Biodegradable Municipal Waste (BMW), which may be landfilled. In 2016, an estimated 2.6 million tonnes of BMW will require diversion from landfill in Ireland. Recycling of dry paper, reuse of textiles and home composting will divert significant quantities of BMW. However, to divert the quantities required to comply with the Directive a significant proportion of the Organic Fraction of Municipal Solid Waste (OFMSW) will require treatment in centralised biological facilities.

A survey was undertaken of composting facilities in Ireland to ascertain present capacity, present technology employed and types of feedstock composted. A generic model (consisting of in-vessel composting followed by aerated static pile composting) was generated from technical, economic and environmental data obtained from the survey. The generic model is utilized to ascertain the effect of economies of scale, the effect of gate fees on potential profit per tonne feedstock and the greenhouse gas contribution of the composting process. The model was investigated for four scenarios ranging from small (11ktpa) to very large (220ktpa). The economic analysis indicated that a potential for profit of $€ 52.5 / \mathrm{t}-€ 65.4 / \mathrm{t}$ was achievable without sale of compost. The direct greenhouse gas production equated to $566 \mathrm{kgCO}_{2} / \mathrm{t}$. However considering the "do-nothing" scenario of landfill, $1,175 \mathrm{kgCO}_{2}$ equiv/t is avoided. Thus 1 tonne of BMW saves $609 \mathrm{kgCO}_{2}$ equiv.
\end{abstract}

Keywords: composting, BMW, OFMSW, gate fee, greenhouse-gas analysis. 


\section{Introduction}

BMW is waste, which can undergo aerobic or anaerobic decomposition such as OFMSW, paper, card and textiles. However not all waste types are suitable for composting, textiles are slow to biodegrade and as such are difficult to compost. Paper is made up of 39\% wet paper and 61\% dry paper [1]. Dry paper is suitable for recycling, but wet paper is more suitable for composting.

The implementation of the Landfill Directive [2] will lead to a significant reduction in the quantities of BMW consigned to landfill. In 2003 Ireland produced 3 million tonnes of municipal solid waste (MSW), of which 2 million tonnes may be classed as BMW [3]. Between 2002 and 2003 household waste grew at a rate of $4.5 \%$ pa. If this growth rate continues to 2016,3 million tonnes of biodegradable waste will be generated [4]. In 1995, the base year for the Landfill Directive [2], 1.3 million tpa of BMW were generated in Ireland. Therefore in 2016, only 450,000tpa of BMW may be consigned to landfill. Thus an estimated 2.6 million tonnes of BMW will require diversion from landfill.

Figure 1 shows the breakdown of BMW; approximately $220 \mathrm{~kg} / \mathrm{pe}$ of BMW may be collected for biological treatment.

\section{Composting industry in Ireland}

A survey of existing facilities was carried out [5]. In total 17 facilities were surveyed. The questionnaire was aimed at assessing the technical, economic and environmental parameters of composting.

It was found that the compost produced at the facilities is not sold, it is either given away for free or the operators of the facilities have a demand for the compost. Only two of the facilities surveyed located a market for the compost. Thus the gate fee for accepting waste is often the only source of revenue for many of the composting facilities. The fee charged for accepting waste ranged from $€ 60-155 / \mathrm{t}$.

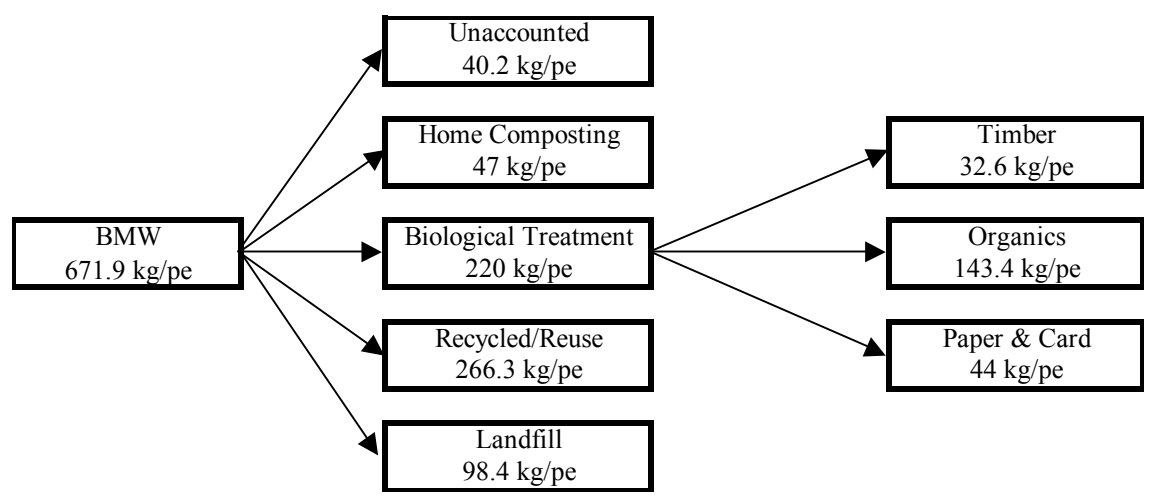

Figure 1: Breakdown of biodegradable municipal waste. 


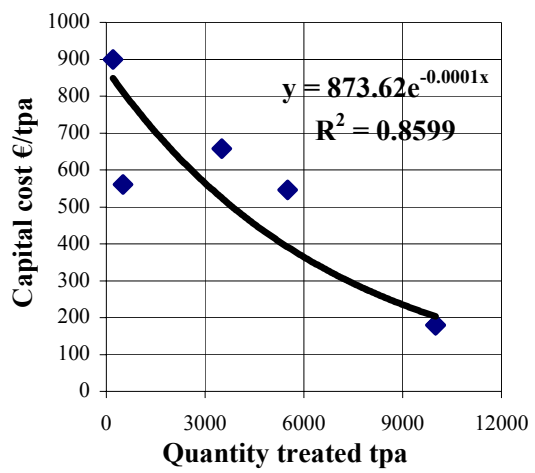

(a): Aerated static piles

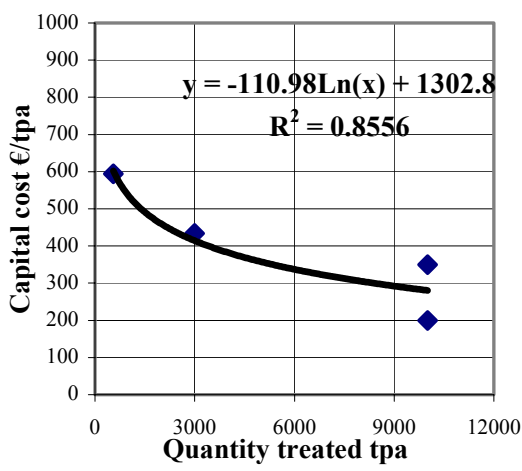

(b): In-vessel

Figure 2: Capital cost/tpa of (a) aerated static piles and (b) in-vessel composting.

The two most common methods of composting in Ireland were aerated static piles and in-vessel composting. Surprisingly the capital cost/tpa of in-vessel is cheaper than that of aerated static piles if less than 6ktpa is treated (figure 2).

Green waste does not require in-vessel composting. However waste that contains meat, such as OFMSW, must be composted in a closed reactor, which cannot be by-passed (in-vessel composting) in order to comply with the Animal By-Product Regulations (1774/2002) [6].

\section{Scenarios investigated}

The technology modelled employs two weeks retention time in in-vessel composting followed by eight weeks retention time in aerated static piles. Land prices, planning or waste permit costs are not considered. The scenarios to be modelled are:

1a. Small region: 50,000pe, $11 \mathrm{ktpa}$, Waterford City;

1b. Medium region: 120,000pe, 26.4ktpa, Cork City;

1c. Large region: $400,000 \mathrm{pe}, 88 \mathrm{ktpa}$, Cork City and County;

1d. Very large region: 1,000,000pe, 220ktpa, Dublin.

The scenarios are applicable to specific geographical locations in Ireland. Scenario 1d. is based on the population of greater Dublin. However it is assumed that the region will be served by two facilities treating $110 \mathrm{ktpa}$.

\section{Technical analysis}

The scenarios investigated range greatly in size, thus the effects of economies of scale may be explored. Table 1 shows the technical analysis of the four scenarios under investigation. From the survey it was estimated that each tonne of 
biowaste treated via in-vessel composting followed by aerated static piles, required $35 \mathrm{~kW}_{\mathrm{e}} \mathrm{h}$ and 2 litres of diesel. The analysis shows each tonne of BMW treated generates $488 \mathrm{~kg}$ of compost.

Table 1: $\quad$ Technical analysis of composting scenarios.

\begin{tabular}{|l|r|r|r|r|}
\hline \multirow{2}{*}{ Technical parameters } & \multicolumn{4}{|c|}{ Scenarios } \\
\cline { 2 - 5 } & \multicolumn{1}{|c|}{$\mathbf{1 a}$} & \multicolumn{1}{|c|}{$\mathbf{1 b}$} & \multicolumn{1}{c|}{$\mathbf{1 c}$} & \multicolumn{1}{c|}{$\mathbf{1 d}$} \\
\hline Population equivalent & 50,000 & 120,000 & 400,000 & $1,000,000$ \\
BMW collected kg/pe & 220 & 220 & 220 & 220 \\
BMW treated tpa & 11,000 & 26,400 & 88,000 & 220,000 \\
Dry solids content of BMW (47.9\%) tpa & 5,269 & 12,646 & 42,152 & 105,380 \\
Volatile solids content (37.3\% wet) tpa & 4,103 & 9,847 & 32,824 & 82,060 \\
Destrution of volatiles at facility (50\%) tpa & 2,052 & 4,924 & 16,412 & 41,030 \\
Dry soids out tpa & 3,218 & 7,722 & 25,740 & 64,350 \\
Compost produced (60\% dry solids) tpa & 5,363 & 12,870 & 42,900 & 107,250 \\
Electricity required (35kWeh/t) & 385,000 & 924,000 & $3,080,000$ & $7,700,000$ \\
Diesel required (2l/t) & 22,000 & 52,800 & 176,000 & 440,000 \\
\hline
\end{tabular}

\section{Economic analysis}

In figure $1 b$, eqn (1) is generated which allows calculation of the capital cost of an in-vessel composting facility with a capacity less than 10ktpa. The facilities that participated in the survey had a capacity of less than 10ktpa. This highlights the relative "youth" of the industry in Ireland. A number of proposals are mooted for larger developments. Detailed analysis of facilities and discussion with developers allowed generation of capital cost data for larger developments as outlined in eqn. (2).

$$
\begin{array}{ll}
y=-110.98 \operatorname{Ln}(x)+1302.8 & (<10 \mathrm{ktpa}) \\
y=5495.6 \mathrm{x}^{-0.3058} & (>10 \mathrm{ktpa})
\end{array}
$$

where,

$y$ is the capital cost of the composting facility in units $€ /$ tpa $x$ is the quantity of waste to be treated in units of tpa

The operating costs generated from the survey for in-vessel composting followed by aerated static piles ranged from $€ 20-60 / t$, with a mean of $€ 35 / t$. This excluded the cost of electricity and fuel. In table 2 the price of diesel is $€ 1 / 1$ and electricity costs are based on a standing charge of $€ 7.88 / \mathrm{month}, 48,000 \mathrm{~kW}_{\mathrm{e}} \mathrm{h}$ at $€ 0.1419 / \mathrm{kW}_{\mathrm{e}} \mathrm{h}$ and any remaining units at $€ 0.1209 / \mathrm{kW}_{\mathrm{e}} \mathrm{h}$. The gate fee for accepting biological waste ranged from $€ 60-155 / \mathrm{t}$. For this analysis it was estimated that a gate fee of $€ 100 / t$ was attainable. The effect of sale of compost on the economic viability of the project is investigated. Either no market is available for the compost produced or a sale price of $€ 40 / \mathrm{t}$ for the compost produced is obtained (sale price of compost at one facility). From table 2 the potential profit ranges from $€ 52.5 / \mathrm{t}-€ 65.4 / \mathrm{t}$ with a market for compost and $€ 33 / \mathrm{t}$ - €45.9/t without a market for compost. The economies of scale are evident. 


\section{Sensitivity analysis}

\subsection{Critical variables}

Table 2 assumed that a gate fee of $€ 100 / t$ was attainable and a market for compost of $€ 40 / t$ may be obtained. It also estimated operating costs of $€ 35 / t$. A sensitivity analysis was carried out to determine the effects of these variables on the potential profit.

Table 2: $\quad$ Economic analysis of composting scenarios.

\begin{tabular}{|c|c|c|c|c|}
\hline \multirow{2}{*}{ Economic parameters } & \multicolumn{4}{|c|}{ Scenarios } \\
\hline & $1 a$ & $1 b$ & $1 \mathrm{c}$ & 1d \\
\hline \multicolumn{5}{|l|}{ Liabilites } \\
\hline Capital cost & $3,520,000$ & $6,468,000$ & $14,960,000$ & $35,200,000$ \\
\hline \multicolumn{5}{|l|}{ Annual liabilities } \\
\hline Cost of capital $(\mathrm{r}=5 \%, \mathrm{~N}=20$ years $)$ & 282,454 & 519,009 & $1,200,429$ & $2,824,539$ \\
\hline Operating costs $(€ 35 / \mathrm{t})$ & 385,000 & 924,000 & $3,080,000$ & $7,700,000$ \\
\hline Fuel $(21 / t * € 1 / 1)$ & 22,000 & 52,800 & 176,000 & 440,000 \\
\hline Electricity & 47,649 & 112,814 & 373,475 & 932,033 \\
\hline Total annual liabilities & 737,103 & $1,608,623$ & $4,829,904$ & $11,896,572$ \\
\hline \multicolumn{5}{|l|}{ Annual assest } \\
\hline Gate fee $(€ 100 / t)$ & $1,100,000$ & $2,640,000$ & $8,800,000$ & $22,000,000$ \\
\hline Sale of compost $(€ 40 / \mathrm{t})$ & 214,520 & 514,800 & $1,716,000$ & $4,290,000$ \\
\hline Total annual assest & $1,314,520$ & $3,154,800$ & $10,516,000$ & $26,290,000$ \\
\hline \multicolumn{5}{|l|}{ Potential profit } \\
\hline With sale of compost $(€)$ & 577,417 & $1,546,177$ & $5,686,096$ & $14,393,428$ \\
\hline$(€ / t)$ & 52.5 & 58.6 & 64.6 & 65.4 \\
\hline Without sale of compost $(€)$ & 362,897 & $1,031,377$ & $3,970,096$ & $10,103,428$ \\
\hline$(€ / t)$ & 33.0 & 39.1 & 45.1 & 45.9 \\
\hline
\end{tabular}

\subsection{Sale price of compost}

For the sensitivity analysis the price of compost ranged from $€ 0 / t$ (no market for heat) to $€ 50 / t$. Due to the significant quantity of biodegradable waste that will require biological treatment ( 1 million tpa in 2016), a significant quantity of compost or similar material such as digestate will be produced. Thus it is unlikely that a market of $€ 50 / \mathrm{t}$ will be attainable at all facilities. Figure 3 shows how the potential profit changes with a change in the compost sale price.

It was found that a market for compost significantly increases the potential for profit. In scenario 1a the potential profit rises from $€ 33 / \mathrm{t}$ with no market for compost to $€ 57.4 / \mathrm{t}$ if compost is sold for $€ 50 / \mathrm{t}$. 
308 Waste Management and the Environment III

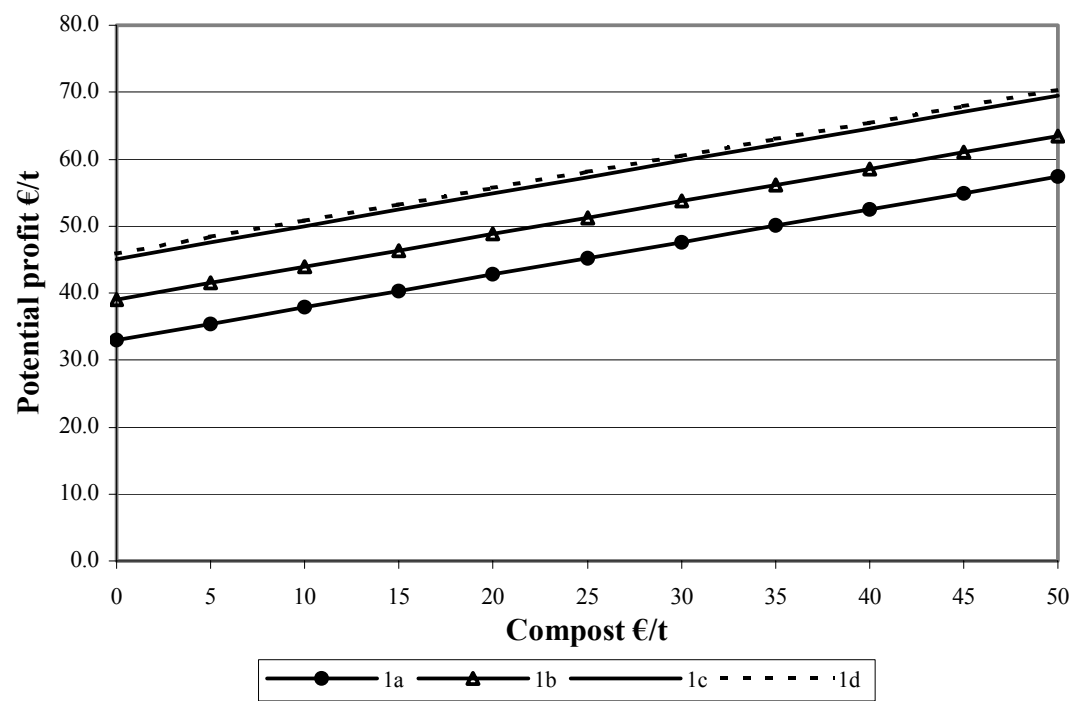

Figure 3: The change in potential profit based on a change in compost sale price.

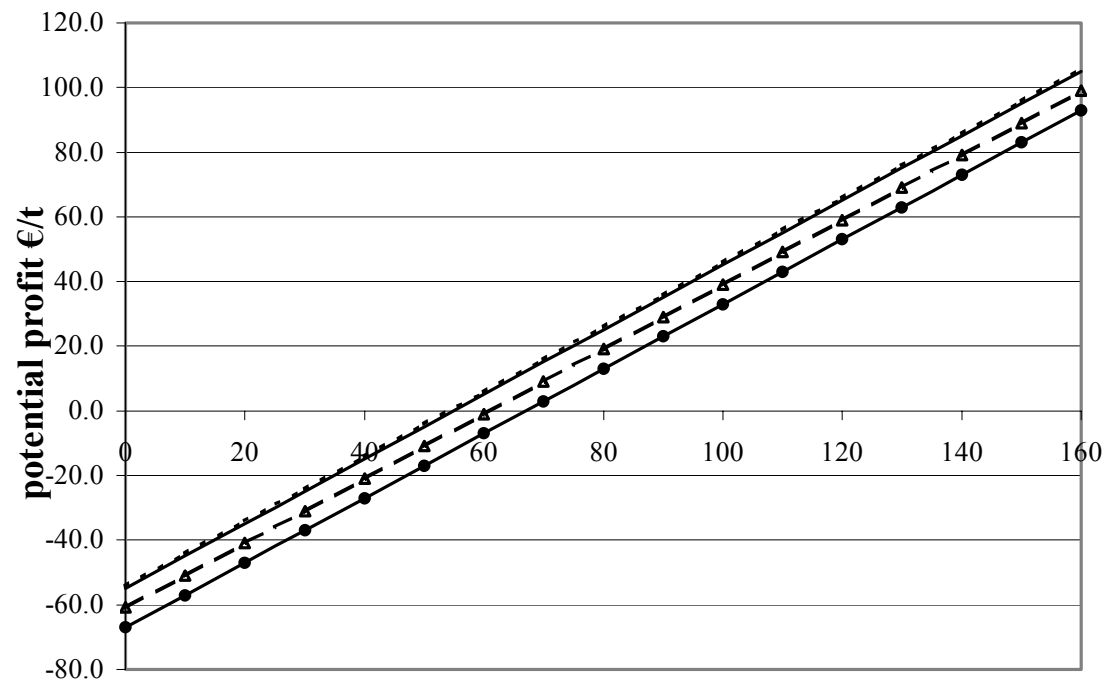

Gate fee $€ /$ t

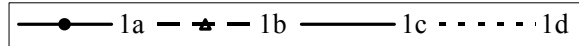

Figure 4: Change in potential profit based on a change in gate fee. 


\subsection{Gate fee}

The gate fee for accepting biodegradable waste in Ireland ranges from $€ 60 / \mathrm{t}$ $€ 155 / \mathrm{t}$; the analysis in table 2 is based on a gate fee of $€ 100 / \mathrm{t}$. Changes in gate fee result in changes in the potential profit as highlighted in figure 4 . If no market for compost exists the gate fee required to break even would range from $€ 54.1 / \mathrm{t}-€ 67 / \mathrm{t}$.

\subsection{Operating costs}

The operating costs of in-vessel composting ranged from $€ 20-60 / t$ : the analysis in table 2 is based on an operating cost of $€ 35 / \mathrm{t}$. Figure 5 represents how the potential for profit decreases with increasing operating costs. The operating costs analysed ranged from $€ 10-70 / \mathrm{t}$. The corresponding potential profit ranged from $€ 12.2 / \mathrm{t}-€ 72.2 / \mathrm{t}$ in scenario $1 \mathrm{~d}$ with no market for compost.

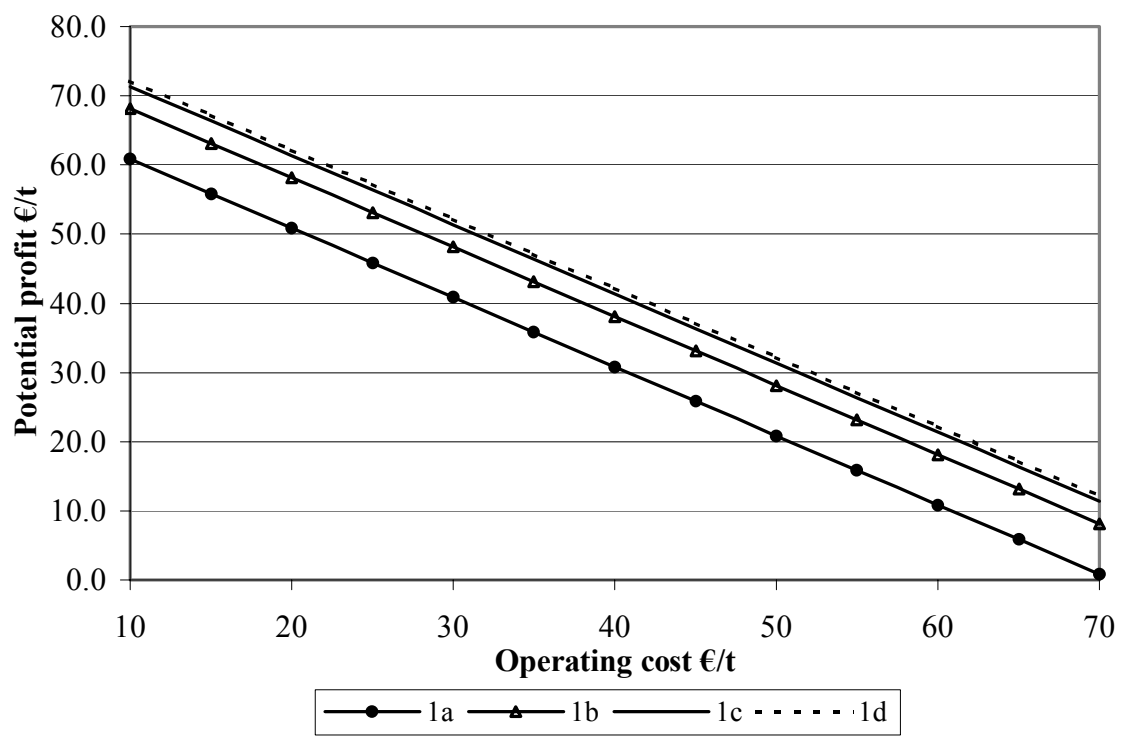

Figure 5: Change in potential profit based on a change in operating cost.

\section{Environmental analysis}

It is estimated that on a dry basis BMW contains $47.7 \%$ carbon, $6.4 \%$ hydrogen, $38.7 \%$ oxygen, $2.1 \%$ nitrogen, $0.3 \%$ sulphur and $5.1 \%$ ash [adapted from 7 ]. Analysis of components of BMW that are modelled in the compost analysis leads to a moisture content of 52.1\% [5]. Then the BMW may be described as

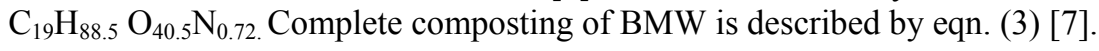

$$
\mathrm{C}_{\mathrm{a}} \mathrm{H}_{\mathrm{b}} \mathrm{O}_{\mathrm{c}} \mathrm{N}_{\mathrm{d}}+[(4 \mathrm{a}+\mathrm{b}-2 \mathrm{c}-3 \mathrm{~d}) / 4] \mathrm{O}_{2}=\mathrm{aCO}_{2}+[(\mathrm{b}-3 \mathrm{~d}) / 2] \mathrm{H}_{2} \mathrm{O}+\mathrm{dNH}_{3}
$$


From eqn (3) it may be calculated that 1 tonne of BMW may generate $836 \mathrm{kgCO}_{2}$ if $100 \%$ destruction is experienced. However an OECD report on sewage sludge suggests that only $65 \%$ of volatiles are destroyed over time. If this figure were taken for BMW then 1t of BMW would emit $543 \mathrm{kgCO}_{2}$. In Ireland electricity come from various source such as coal, natural gas, oil peat and renewable sources. However on average $651 \mathrm{gCO}_{2} / \mathrm{kW}_{\mathrm{e}} \mathrm{h}$ is released. Work by Murphy et al. [9] estimates that diesel emits $2.69 \mathrm{kgCO}_{2} / 1$. The analysis of greenhouse house gas may be viewed in table 3 .

Table 3: Environmental analysis of composting scenarios.

\begin{tabular}{|c|c|c|c|c|}
\hline \multirow{2}{*}{ Environmental analysis } & \multicolumn{4}{|c|}{ Scenarios } \\
\hline & $1 \mathrm{a}$ & $1 b$ & $1 \mathrm{c}$ & $1 \mathrm{~d}$ \\
\hline \multicolumn{5}{|l|}{ Gross greenhouse gas production } \\
\hline Degradation of BMW $\left(543 \mathrm{~kg} \mathrm{CO}_{2} / \mathrm{t}\right)$ & 5,973 & 14,335 & 47,784 & 119,460 \\
\hline Electricity imported $\left(651 \mathrm{~g} \mathrm{CO}_{2} / \mathrm{kW}_{\mathrm{e}}\right)[8]$ & 251 & 602 & 2,005 & 5,013 \\
\hline Diesel utilised $\left(2.69 \mathrm{~kg} \mathrm{CO}_{2} / 1\right)[9]$ & 6 & 13 & 44 & 110 \\
\hline Total gross greenhouse gas ( $\mathrm{t} \mathrm{CO}_{2}$ equivalent) & 6,229 & 14,950 & 49,833 & 124,583 \\
\hline (kg CO 2 equivalent/ t BMW) & 566 & 566 & 566 & 566 \\
\hline \multicolumn{5}{|l|}{ Net greenhous gas production } \\
\hline Gross geenhouse gas & 6,229 & 14,950 & 49,833 & 124,583 \\
\hline Landfill gas $\left(1,175 \mathrm{~kg} \mathrm{CO}_{2} / \mathrm{t} \mathrm{BMW}\right)$ & 12,925 & 31,020 & 103,400 & 258,500 \\
\hline Total net greenhouse gas ( $\mathrm{t} \mathrm{CO}_{2}$ equivalent) & $-6,696$ & $-16,070$ & $-53,567$ & $-133,917$ \\
\hline ( $\mathrm{kg} \mathrm{CO}_{2}$ equivalent/ $\mathrm{t} \mathrm{BMW}$ ) & -609 & -609 & -609 & -609 \\
\hline
\end{tabular}

From table 3 it may be noted that every tonne of BMW treated via composting will release $566 \mathrm{kgCO}_{2}$. However as this waste is composted it is diverted from landfill and landfill gas is not produced. From Box 1 it can be seen that $1 \mathrm{~m}^{3}$ of landfill gas emits on average $4.857 \mathrm{kgCO}_{2}$ if the landfill gas is collected and combusted. If $65 \%$ of the volatiles in the BMW were destroyed in the landfill then $1 \mathrm{t}$ of BMW would produce $242 \mathrm{~m}^{3}$ of landfill or $1,175 \mathrm{kgCO}_{2}$. The net greenhouse gas production indicates that every tonne of BMW treated via composting saves $609 \mathrm{kgCO}_{2}$.

Box 1: $\quad$ Greenhouse-gas emissions per $\mathrm{m} 3$ of landfill gas.

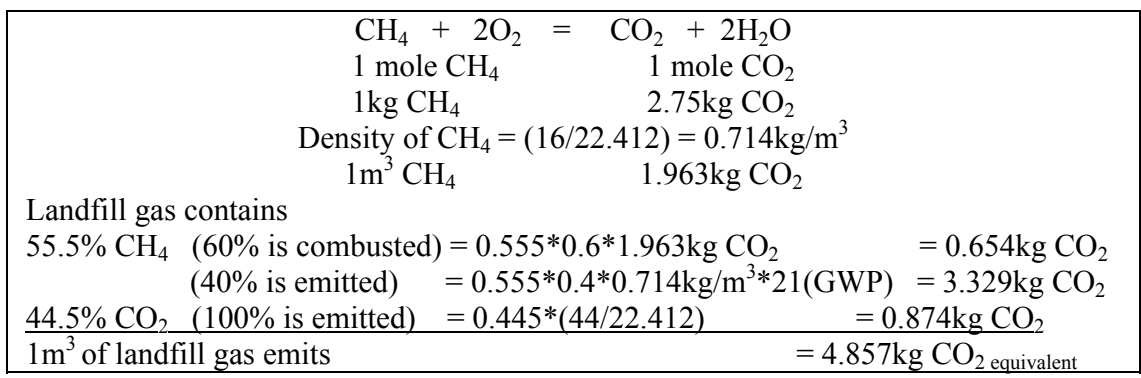




\section{Conclusions}

- Composting reduces the mass of BMW to $48.8 \%$ of the starting material and produces compost that may be used in agriculture in accordance with the Animal By-Products Regulation.

- The composting process has a net energy input of $35 \mathrm{~kW}_{\mathrm{e}} \mathrm{h} / \mathrm{t}$ treated and $2 \mathrm{l} / \mathrm{t}$ of diesel.

- Economies of scale are important. The potential for profit varies from $€ 33 / \mathrm{t}$ to $€ 45.9 / \mathrm{t}$ for facilities treating $11 \mathrm{ktpa}$ to $220 \mathrm{ktpa}$.

- A market for compost can aid the financial viability of a composting facility. If no market for compost is located the gate fee is the only revenue available to the facility. The potential profit varies from $€ 33 / \mathrm{t}$ without sale of compost to $€ 52.5 / \mathrm{t}$ with sale of compost for a plant treating $11 \mathrm{ktpa}$.

- A sensitivity analysis shows that a change in the sale price of compost, gate fee attainable and operating cost has a significant effect on the potential profit of a composting facility.

- The greenhouse gas analysis shows that 1 tonne of BMW treated via composting produces $566 \mathrm{kgCO}_{2}$. However as this waste is no longer consigned to landfill $1,175 \mathrm{kgCO}_{2}$ equivalent is avoided. Thus 1 tonne of BMW saves $609 \mathrm{kgCO}_{2}$ equivalent.

\section{Acknowledgements}

Niamh Power is funded by the Irish Research Council for Science, Engineering and Technology under the Embark Initiative.

\section{References}

[1] Murphy J.D., McKeogh E., Technical, economic and environmental analysis of energy production from municipal solid waste, Renewable Energy, 29 pp. 1043-1057, 2004.

[2] Directive 1999/31/EC of the Council of the European Union of the $26^{\text {th }}$ of April 1999, on the landfill of waste. Official Journal of the European Parliament L 182/01 June 1999.

[3] Environmental Protection Agency, National Waste Database 2003 Interim Report. P.O. Box 3000, Johnstown Castle Estate, Co. Wexford, Ireland, 2004.

[4] Central Statistics Office, Population and Labour Force Projections 20062036 available at Central Statistics Office, Information Section, Skehard Road, Cork.

[5] Power N., The potential for $\mathrm{CH}_{4}$ enriched biogas as a transport fuel in Ireland, Masters thesis, Cork Institute of Technology, unpublished, 2006. 
[6] Regulation no 1774/2002of the European Parliament and of the Council of 3 October 2002 on the laying down health rules concerning animal byproducts not intended for human consumption. Official Journal of the European Parliament L273/1. November 2002.

[7] Tchobanoglous G., Theisen H. \& Vigil S., Integrated Solid Waste Management, International Edition, McGraw-Hill, 1993.

[8] Howley M. \& Ó Gallachóir B., Energy in Ireland 1990-2003 trends issues and indicators, Sustainable Energy Ireland, January 2005.

[9] Murphy J.D., McKeogh E. \& Kiely G., Technical, economic and environmental analysis of biogas utilisation, Renewable Energy 77 pp. 407-427, 2004. 